\section{MACROSCOPIC AND MICROSCOPIC LESIONS CHANGE OF DERMATITIS DOG WITH TRIGONA SP HONEY TREATMENT}

KEY WORDS:Honey, Trigona spp, chronic dermatitis, dogs

\section{Nyoman}

Suartha*

\section{Luh Made} Sudimartini

\section{Putu Devi}

Jayanthi
Departement of Clinical Veterinary, Faculty of Veterinary Medicine Udayana University Denpasar Bali Indonesia, Jl. P. B. Sudirman, Denpasar, Bali, Indonesia 80234. *Corresponding Author

Departement of Clinical Veterinary, Faculty of Veterinary Medicine Udayana University Denpasar Bali Indonesia, Jl. P. B. Sudirman, Denpasar, Bali, Indonesia, 80234.

Departement of Clinical Veterinary, Faculty of Veterinary Medicine Udayana University Denpasar Bali Indonesia, Jl. P. B. Sudirman, Denpasar, Bali, Indonesia 80234.

Ni Putu Ayu Dewi Faculty of Mathematics And Natural Sciences Udayana University Denpasar Wijayanti Bali Indonesia, Kampus Bukit Jimbaran Bali Indonesia

Dermatitis is a term used to describe inflammation and damage of the layers of the skin. The causative agents are bacterial, fungal, mold, and parasitic infestations. Dermatitis has become problems in various regions in Indonesia and some other countries. Dermatitis often causes an unpleasant and disgusting feeling for the owner. Skin damage occurs to the dermis, thus showing clinical symptoms of hair loss, itching, redness of the skin, skin ulcers, and a bad smell of the animals. This study aims to determine the effect of giving honey from Trigona bees to improve the skin layer structure of patients with dermatitis in dogs and to see the development of skin lesions macroscopically. Research method: 10 dogs diagnosed with complex dermatitis were given fresh honey of $5 \mathrm{ml} /$ day/dog. The treatment is given orally once a day for 35 days. Clinical observation of the wound healing process on the skin was observed every week for 5 weeks, and histopathological observations of the skin were carried out on the 0,7 , and 21 days. The results showed that giving fresh honey was able to repair skin damage with dermatitis lesions. It could be seen from the decrease in symptoms of erythema and the start of hair growth at the site of alopecia lesions. Histologically there was a decrease in the number of inflammatory cells $(p<0.05)$ in the administration of honey. We concluded that Trigona's honey could be used as an herbal ingredient for treating dermatitis in dogs

\section{INTRODUCTION}

Dermatitis is a term used to describe inflammation and damage of the layers of the skin. The causative agents are bacterial infections (Suartha et al., 2017), fungal and mold infections (Putri et al., 2018), and parasitic infestations (Priasdhika and Hadi, 2014). Dermatitis has become problems in various regions in Indonesia (Tjahajati et al., 2014; Widyastuti et al., 2012), and some other countries (Totton et al., 2010). Dermatitis often causes an unpleasant and disgusting feeling for the owner. Skin damage occurs to the dermis layer (Purnama et al., 2019), thus showing clinical symptoms of hair loss, itching, redness of the skin, skin ulcers, and a bad smell of the animals (Widyastuti et al., 2012; Tjahajati et al., 2014). In severe dermatitis case, the problem reaches above $70 \%$ of the body surface area, with various combinations of clinical symptoms and lesions (Purnama et al.,2019).

The use of honey as a medicine and nutrition has been carried out since ancient times because of the content of functional ingredients (Nayik et al., 2014). Honey can be used as an alternative medicine to replace synthetic antimicrobials (Draiaia et al., 2015). The therapeutic component of honey depends on flowers as a source of food for the bees. High antioxidants and antibacterials were reported in honey from Trigona spp (Baby et al., 2018). Honey is an antioxidant because it contains polyphenols in the form of phenolic acids (chlorogenic, ferulic, caffeic, ellagic, vanillic, benzoic, cinnamic, coumaric acids) and flavonoids (pinocembrin, apigenin, hesperitin, chrysin, quercetin, luteolin, myricetin, pinobanksin, galangin, kaempferol) (Nayik and Nanda, 2016a; Baby et al., 2018), and vitamin C to boost the immune system. The antibacterial components of honey are hydrogen peroxide, and phenolics (Garedew et al., 2003; Gambogou et al., 2018; Kafaween et al., 2019). The antioxidant activity of honey represents an important added value of honey for use in nutritional and pharmaceutical applications (Adeyemo et al., 2017). The use of honey as medicine and nutrition in humans has been carried out since long times ago (Nayik et al., 2014; Baby et al., 2018). However, the use in animals, especially the treatment of dermatitis in dogs has not been reported.This study aims to determine the effect of Trigona sp honey administration on improving the skin layer structure in dogs with dermatitis and to observe the development of skin lesions microscopically.

\section{MATERIALS AND METHODS}

\section{Ethical approval}

The procedures performed in this study were guided by the principles of animal welfare, Animal Welfare Act the Faculty of Veterinary Medicine of Udayana University, Bali Indonesia (No B/81/UN14.2.9/PT.01.04/2021).

\section{Research design}

This study used 10 dogs diagnosed with complex dermatitis, each sample was given $5 \mathrm{ml}$ of fresh honey every day for 5 weeks. All dogs were adapted to the study environment for 14 days before being given treatment. Dogs are bathed regularly every week. The drug was given orally once a day, then the skin wound healing process was observed clinically and histopathologically. Dermatitis wound healing was microscopically observed every day until day 35 (5 weeks). The microscopic parameter observed was the healing progress of dermatitis lesions. Then biopsy was performed on day 0,7 , and 21 with a size of $0.5 \times 0.5 \mathrm{~cm}^{2}$.The skin tissue from the biopsy was fixed with $10 \%$ formalin phosphate buffer for 48 hours. Then the fixed tissue was made into histology preparations for HE staining.

\section{Histopathological Preparation}

Skin preparations with a thickness of $\pm 3 \mathrm{~mm}$ are inserted into a tissue cassette and then dehydrated by soaking the preparation in a graded alcohol solution. Which successively start from $70 \%, 80 \%, 90 \%$, then alcohol absolute I, absolute II, 
xylol I, xylol II, paraffin, and finally to paraffin II. Each immersion was carried out for two hours. Then the tissue was cut with a microtome thickness of 5-6 m. Next, the result in the form of a ribbon is placed in warm water to avoid wrinkling due to cutting. The preparation was removed, placed on an object glass, and dried in an incubator at $60^{\circ} \mathrm{C}$ for 24 hours.

\section{Hematolksilin Eosin Staining}

Deparaffinization was carried out by soaking the preparations in xylol 1 and 2 for two minutes each. Furthermore, redehydration was carried out by sequential immersion in absolute alcohol, 95\% alcohol, and $80 \%$ alcohol each for two minutes, then washed with running water. Staining with Hematoxylin was carried out for 8 minutes, then rinsed with running water, next washed with Lithium carbonate for 15-30 seconds, rinsed with running water, and after that stained with eosin for 2-3 minutes, rinsed, and then dried. The preparations were immersed in 95\% alcohol and absolute alcohol 10 times each, then in absolute alcohol 2 for 2 minutes. Then into xylol 1 for 1 minute and xylol 2 for 2 minutes. The preparation was then dripped with premium adhesive, covered with a cover glass, and examined under a microscope.

\section{RESULT}

The result of the present study showed that all dogs (100\%) have type lesion dermatitis alopecia, 70\% erythema, 60\% macula, $30 \%$ papula, and $1 \%$ vulnus, respectively. Hair growth began to appear in weeks- 4 after treatment, skins erythema still detected until weeks -3 , with decreased severity, as well as lesion macula and papula (Table 1). The result of photomicrograph skin dermatitis showed that the administration of Trigona's honey had a significant $(p<0.05)$ effect on decreased inflammatory cells (Table 2 And Fig 1)

Table 1 Macroscopis healing of dermatitis skins with Trigona's honey treatment

\begin{tabular}{|c|c|c|c|c|c|c|c|}
\hline No & Type of Lesions & Weeks- 0 & Weeks -1 & Weeks-2 & Weeks-3 & Weeks-4 & Weeks- 5 \\
\hline 1 & Alopesia in Abdomen & 9 out of 10 & 9 out of 10 & 9 out of 10 & 9 out of 10 & 1 out of 10 & 1 out of 10 \\
\hline 2 & Alopesia in neck & 7 out of 10 & 7 out of 10 & 8 out of 10 & 8 out of 10 & 1 out of 10 & 1 out of 10 \\
\hline 3 & Alopesia extremitas caudal & 8 out of 10 & 9 out of 10 & 8 out of 10 & 8 out of 10 & 1 out of 10 & 1 out of 10 \\
\hline 4 & Alopesia extremitas cranial & 6 out of 10 & 8 out of 10 & 7 out of 10 & 10 out of 10 & 1 out of 10 & 1 out of 10 \\
\hline 5 & eritrema in abdomen & 6 out of 10 & 6 out of 10 & 6 out of 10 & 6 out of 10 & 1 out of 10 & 1 out of 10 \\
\hline 6 & eritrema in neck & 7 out of 10 & 7 out of 10 & 7 out of 10 & 7 out of 10 & 1 out of 10 & 1 out of 10 \\
\hline 7 & Eritrema extremitas caudal & 7 out of 10 & 7 out of 10 & 7 out of 10 & 7 out of 10 & 1 out of 10 & 1 out of 10 \\
\hline 8 & Makula di ekstremitas caudal & 6 out of 10 & 6 out of 10 & 6 out of 10 & 6 out of 10 & 1 out of 10 & 1 out of 10 \\
\hline 9 & Makula in abdomen & 6 out of 10 & 6 out of 10 & 6 out of 10 & 6 out of 10 & 1 out of 10 & 1 out of 10 \\
\hline 10 & Vulnus extremitas & 1 out of 10 & 1 out of 10 & 1 out of 10 & 1 out of 10 & 1 out of 10 & 1 out of 10 \\
\hline 11 & Papula in abdomen & 3 out of 10 & 3 out of 10 & 3 out of 10 & 3 out of 10 & 1 out of 10 & 1 out of 10 \\
\hline 12 & papula extremitas cranial & 3 out of 10 & 3 out of 10 & 3 out of 10 & 3 out of 10 & 1 out of 10 & 1 out of 10 \\
\hline 13 & papula in neck & 3 out of 10 & 3 out of 10 & 3 out of 10 & 3 out of 10 & 1 out of 10 & 1 out of 10 \\
\hline 14 & Hairs to grow & 0 out of 10 & 0 out of 10 & 0 out of 10 & 1 out of 10 & 10 out of 10 & 10 out of 10 \\
\hline
\end{tabular}

The results of the present study showed that there was a significant decrease $(\mathrm{P}<0.05)$ in the number of inflammatory cells on day-0, day-7 and day-2l (Table 2). The histopathological changes of the skin can be seen in Fig 1 .

Table 2. Examination of Inflamatory cell on Skins Dog After treatment Honey's Trigona

\begin{tabular}{|c|c|c|c|}
\hline \multirow{2}{*}{ Treatment } & \multicolumn{3}{|c|}{ Mean of inlamatory cells } \\
\cline { 2 - 4 } & day -0 & day -7 & day -21 \\
\hline Trigona's Honey & $21.33 \pm 5.99^{\mathrm{a}}$ & $13.17 \pm 5.78^{\mathrm{b}}$ & $5.17 \pm 2.23^{\mathrm{c}}$ \\
\hline
\end{tabular}

Note: different letter in the direction of the rows indicate significant different $(\mathrm{P}<0.05)$

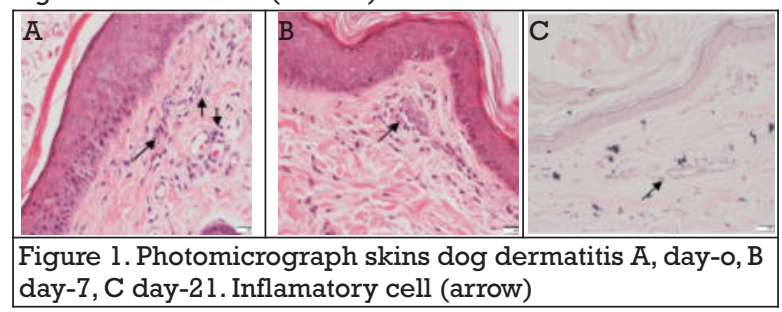

\section{DISCUSSION}

Type of dermatitis lesions seen in sample dogs were alopecia, erythema, macula, papula, and vulnus. The spread on abdomen, neck, extremitas cranial, and caudal. All dogs $(100 \%)$ have type lesion dermatitis alopecia, $70 \%$ erythema, $60 \%$ macula, $30 \%$ papula, and $1 \%$ vulnus, respectively on each dog. The severity of dermatitis is usually based on the distribution of lesions on the body surface and multiple types of lesions and infiltration inflammatory cell-like polymo rphonuclear and mononuclear (Purnama et al., 2016). In this research, the severity of lesions is moderate. Hair growth began to appear in weeks-4 after treatment, skin erythema still detected until weeks -3 , with decreased severity, as well as lesion macula and papula (Table 1). That indicated healing has occurred.

|www.worldwidejournals.com
The administration of Trigona's honey had a significant $(p<0.05)$ effect on decreasing inflammatory cells (Table 2). The simplest interpretation of our findings on day 7 and day 21 is shown in Figure 1. It was found to reduce epidermal thickening and decrease the number of inflammatory cells, which indicate the healing of skins. Karayannopoulou et al. (2011) reported skins healing could be observed by looking at the histopathological changes such as the level of cellular infiltration of collagen production, neovascularization, and epithelial thickness.

A large number of inflammatory cells indicate the severity of the skins damage. In this research, infiltration of the inflammatory cell was distributed on the dermis. It is categorized as moderate. Trigona's honey contains flavonoids which have the effect of reducing migration of inflammatory cells to skins damage. The flavonoids had increased supply ions hydrogen to neutralize the toxic effect of free radicals (Nijveldt et al., 2001). Several flavonoid compounds can inhibit leucocyte, degranulation neutrophil, and inhibit the release of histamine (Yuda et al., 2015).

In this study, one sample dog showed no changes in the healing of dermatitis lesions. This could be due to stressful conditions, or there are complications of other diseases or disturbance hormonal, and these were not examinations in this research. The sample dogs in this research come from stray dogs and have different levels of stress. In addition, the different adaptation processes of dogs can cause dogs to be uncomfortable with their new environment. Lestari et al. (2007) reported someone who has a history of atopic diseases could increase vulnerability dermatitis. Other infections like viruses can inhibit decreased inflammatory cells.

\section{CONCLUSION}

We concluded that the Trigona's could be used as an herbal ingredient for treating dermatitis in dogs 


\section{Authors' Contributions}

IN Suartha conceptualized the study and analyzed and wrote the manuscript. Luh Made Sudimartini, and Putu Devi Jayanthi took charge of the sample collection and data analyses. $\mathrm{Ni}$ Putu Ayu Dewi Wijayanti analysis contain of honey Trigona and support in the conduct of the study. All authors finally read and approved the final manuscript.

\section{ACKNOWLEDGIMENTS}

This study was funded by the Institute for research and community service Udayana University by Research Grant of the Udayana University Bali Indonesia. with contract No: B/9948/UN14.4.A/PT.01.05/2021, May $3^{\text {th }} 2021$.

\section{Competing Interests}

The authors declare that they have no competing interests.

\section{REFERENCES}

1. Adeyemo RO, Torimiro N, Akinola SA, Lawal SK, Abolarinwa TO, Adewoye WO. 2017.Study on antibacterial efficacy of different honey types in South Western Nigeria against wound associated bacteria.J Apither. 2(1): 15-19.

2. Baby N, Anil Kumar V, dan Minol V. 2018. Biological And Pharmacological Potentials Of Trigona Irridipennis Bee Products: A Review. World Journal Of Pharmaceutical Research Vol 7(17):651-663

3. Draiaia R, Dainese N, Borin A, Manzinello C, Galina A, Mutinelli F. 2015. Physicochemical parameter and antibiotics residuals in Algerian Honey. Afr J Biotechnol.14(14):1242-1251

4. Gambogou B, Khadimallah H, Bouacha M, Ameyapoh YA. 2018.Antibacterial activity of various honey monofloral and polyfloral from different regions of Algeria against uropathogenic Gram-Negative Bacilli. Journal Of Apitherapy, $4(1): 1-8$

5. Garedew A, Schmolz E., Lamprecht I. 2003. The Antimicrobial activity of Honey of the Stingless Bee Trigona spp. Journal of Apicultural Science 47 (1): $37-49$

6. Kafaween MAA, Hilmi ABM, Khan RS, Bouacha M, Amonov M. 2019. Effect of Trigona honey on Escherichia coli cell culture growth: In vitro study. Journal Of Apitherapy, 5 (2):10-17

7. Karayannopoulou MV, Tsioli P, Loukopoulos T, Anagnostou N, Giannakas I, Savvas, L, Papazoglou E, Kaldrymidou. 2011. Evaluation of the Effectiveness of an Ointment Based on Alkannins/ Shikonins on Second Intention Wound Healing in the Dog. The Canadian Journal ofVet.Res 75: 42-48.

8. Lestari F, Utomo HS. 2007. Factor Associated With Dermatitis Contact In Worker At PT.Inti Panjta Pres Industri.Makara 11(2): 61-68

9. Nayik, G. A., Shah, T. R., Muzaffar, K.,Wani, S. A., Gull, A., Majid, I. and Bhat, F.M. 2014. Honey: its history and religious significance: a review. Universal Journal of Pharmacy 3(1):5-8.

10. Nayik, G. A., Dar, B. N. and Nanda, V. 2016a. Optimization of the process parameters to establish the quality attributes of DPPH radicals scavenging activity, total phenolic content and total flavonoid content of apple (Malus domestica) honey using response surface methodology. International Journal of Food Properties 19(8): 1738-1748.

11. Nijveldt R, Van Nood, E., Van Hoom, D.E.C., Boelens, P.G., Van Norren, K., Van Leeuwen, A.M., 2001. Flavanoids: a Review of probable mechanisms of action and potential applications. Am.J. Clin. Nutr 74: 418-425

12. Priasdika G, dan Hadi UK. 2014. Study Of Ectoparasites Infestation In Pondok Pengayom Satwa Jakarta. Proseding Kivnas ke-13 PDHI. Palembang 23-26 Nopember 2014

13. Purnama KA,Winaya IBO, Suartha IN, Mirah Adi AAA, Erawan IGMK, Kardena IM. 2019. Histopathological Features Of Dog's Skin With Dermatitis . Jurnal Veteriner 20(4):486-496

14. Putri ACA, Suartha IN, Merdana IM, Sudimartini LM. 2018. Neem Leaf Extract Effective Against Microsporum Gypseum Isolated From Dermatitis Dog. IMV 7 (6):608-615.DOI: $10.19087 / 1 \mathrm{mv} .2018 .7 .6 .608$.

15. Suartha IN, Suarjana IGK, Sudimartini LM, Swantara IMD. 2017. In vitro study of antimicrobial activity of combined extracts of Azadiractha indica, Centella Asiatica and Annona muricata leaves against a panel of bacteria isolated from dog dermatitis cases.JAVS, 1(1):

16. Tjahajati I,Widiastuti TA, Erarindah E, Prayitno AD, Rifgiyanto L, Hanafi I. 2014 Types of Patient and Percentage Of Dogs and Cats infected with Endoparasites and Endoparasites Treated At The Jogya Veterinary Clinic 2013-2014.Proseding Kivnas ke-13 PDHI. Palembang 23-26 Nopember 2014.

17. Totton SC,Wandeler, A.I., Ribble, C.S., Rosatte, R.C., McEwen, S.A. 2011 . Stray dog population health in Jodhpur, India in the wake of an animal birth control (ABC) program. PreventiveVeterinary Medicine 98: 215-220.

18. Widyastuti SK, Sutaridewi NM, Utama IH. 2012. Street Dogs Skins Disorder At Several Location In Bali. Buletin Veteriner Udayana. 4(2):81-86.

19. Yuda R, Lanny M,Ratu C.2015. Anti-Inflammatory Activity Test Of Puple Sweet Potato (Ipomea Batatas (L.) Lamk) leaf Ethanol Extract Against Male Rats Wistar.Prosiding Farmasi 1(2): 630-636 